\title{
Board Audit Committee Characteristics and Financial Performance of Selected Commercial Banks in Ghana
}

\author{
John Nana Ekow Baiden \\ Takoradi Technical University, Ghana \\ E-mail: jonylepoks@yahoo.com
}

Received: February 11, 2020

Accepted: March 12, 2020 Published: March 25, 2020

doi:10.5296/ijafr.v10i1.16749

URL: https://doi.org/10.5296/ijafr.v10i1. 16749

\begin{abstract}
The purpose of the study was to examine the influence of board audit committee characteristics on the financial performance of selected commercial banks in Ghana during the period of 2008 to 2017 . The correlational design was employed. The study population was 23 commercial banks licensed under the Bank and Special Deposit Taking Institution Act with audit committee on their board and offices in Ghana as at December 2018. The sample size for the study was 13 commercial banks in Ghana. The lottery method of simple random sampling technique was used to select the 13 banks. The study made use of only secondary data. Statistical tools such as means, standard deviations, Pearson product moment correlation, and linear multiple regression analysis were used to analyse the data. The findings of the study revealed that when banks audit committee increase the frequency of their meetings, increase the number and quality of financial qualifications of member on board and also increase the size of the audit committee members on total board membership, it will have a significant influence on the banks' financial performance. It was recommended to Bank of Ghana (BoG) and managers of the various commercial banks to ensure that audit committee members are independent, meaningfully represented at boards of the banks, and are people with expertise in accounting/finance.
\end{abstract}

Keywords: Bank age, Bank size, Board audit committee, Commercial banks, Financial performance

\section{Introduction}

The usefulness of board audit committee in financial institutions has become a topical issue as evidence mounts on the critical roles it plays in determining the well-being of these institutions. Board audit committee has become key issues in the $21^{\text {st }}$ Century demanding 
efficiency, disclosure, controls, professionalism, and transparency for firms in their pursuit of increase financial performance to meet the needs of the firm. Nevertheless, the much publicised financial institutions collapse of the past few years have influenced researchers to place more attention on the need for strong internal financial controls, putting less emphasis on good corporate governance (Amoateng, Osei, Ofori \& Gyabaa, 2017; Anthony, 2017). The practice of corporate governance is a combination of a number of mechanisms, amongst which is the board audit committee. Research findings have revealed that most financial institutions in Ghana are faced with financial scandals, financial reporting defalcations, and unjustifiable manipulation of accounting policies (Ahlulbaitulaah, 2017). These challenges are all blamed on poor board audit committee practices of the firms (Saani, 2017). Therefore, it is appropriate for researchers in the business fraternity to give scholarly attention to the impact board audit committee characteristics have on financial performance of firms.

Furthermore, the failure of many commercial banks in Ghana recently, corporate governance reforms in Ghana have empowered the role of the board audit committee in the oversight of financial reporting and banks performance (Nkegbe \& Ustarz, 2015; Saah, 2015). The recapitalisation exercise of the central Bank of Ghana in 2018 has created a serious question about the effectiveness of different monitoring devices that were presumed to protect investors' interests (Bank of Ghana, 2019a). One of such control mechanisms is the board audit committee. The problem with banks failure is that when banks get it wrong, there can be drastic consequences for the economy. This can be seen today from the continuing effects of what started in 2007 in the world economy at large and in Ghana in particular.

According to National Development Planning Commission (NDPC, 2018), the economy is still in a rut and although GDP has once again begun to pick up, unemployment remains at the extremely high level and it pervade to other sectors of the economy. A key issue to ensure progress has to be how to make sure banks board audit committee characteristics are efficient in promoting the performance of the banks. Conditional evidence suggests that corporate governance at banks were ineffective at preventing detrimental lending practices, leading to an extremely vulnerable financial system (Saani, 2017).

Theoretically, it should be expected that an effective board audit committee with governance characteristics would promote banks cost minimisation and maximise profitability within the banks. However, the global economic impact of the financial crisis and the alleged role played by board audit committee signify the need for more empirical research on the role of board audit committee on financial performance of banks. Previous studies showed mixed results regarding the effect of board audit committee functions and earning quality of commercial banks. Hamdan et al. (2013) reported an association between board audit committee impact and commercial banks performance. Basuony, Mohamed and Al-Baidhani (2014) also examined the effect of corporate governance on bank financial performance. The study, however, failed to find an association between the magnitude of performance and the audit committee's financial expertise among the independent directors.

The researcher is convinced that it is of great interest to study the relationship between board audit committee characteristics and financial performance of commercial banks. However, 
most of such studies available to the researcher were conducted outside Ghana and focus on a specific board audit committee variable such as board audit committee members' long service, committee member diversity and independence (Aguilera, Judge \& Terjesen, 2018; Ali, 2017). Also, most of the studies made use of primary data which are more subjective since employees of the banks were considered (Ahlulbaitulaah, 2018).

Furthermore, previous literature (Aguilera et al., 2018; Ahlulbaitulaah, 2018; Ali, 2017; Kuta, 2018; Saani, 2017) failed to consider core board audit committee characteristics such as its members required number of non-executive members, its financial expertise and its size on board. It is in view of this that this study seeks to investigate the influence of board audit committee characteristics on financial performance of commercial banks in Ghana using board audit committee variables like frequency of the committee meeting, independence of the committee, size of the committee and financial expert.

\subsection{Purpose of the Study}

The purpose of the study was to examine the influence of board audit committee characteristics such as audit committee independence, audit committee expertise, and audit committee activities and size on the financial performance (ROE and ROA) of selected commercial banks in Ghana during the period of 2008 to 2017.

\subsection{Objectives of the Study}

Based on the purpose of the study, the following specific objectives of the study were formulated to guide the study:

1. Examine the influence of independence of audit committee members on commercial banks' financial performance in Ghana.

2. Determine the influence of audit committee meetings on commercial banks' financial performance in Ghana.

3. Examine the effect of audit committee members' financial expertise on commercial banks' financial performance in Ghana.

4. Examine whether the size of the audit committee on the governing board has influence on commercial banks' financial performance in Ghana.

5. Examine the controlling roles of bank size and age on the influence board audit committee characteristics have on commercial banks' financial performance.

\subsection{Significant of the Study}

Commercial banks in Ghana and other countries stand to benefit from the results of this study as they face with increasing stakeholder expectations in a turbulent financial environment. The findings of the study will serve as a guide on strengthening board audit committee by focusing on variables found to have a strong correlation with financial performance. Similarly, the regulators ought to lay emphasis on board audit committee effectiveness variables particularly on competence, commitment and independence as they strengthen the 
regulatory framework. The study has established a correlation between board audit committee effectiveness variables and financial performance of commercial banks in Ghana. It has therefore, validated the possibility of the agency theorists on the need to place checks and balances for management through good corporate governance particularly effectiveness of the board audit committee.

\subsection{Delimitations}

The study did not cover the entire corporate governance practice of commercial banks. Again, the study was delimited to four facets of board audit committee characteristics: independence, number of meetings, finance expertise, and size on the board. Also, financial performance of the banks was delimited to return on asset (ROA) and return on equity (ROE) ratios of the banks. The study also considered bank size and age as controls. However, the study failed to consider capital structure and growth opportunities as control variables due to lack of secondary data. Also, the study was delimited to commercial banks in Ghana who were in operation before 2008. The duration period of the study was from 2008 to 2017.

\section{Conceptual Framework}

The conceptual framework was developed to examine the relationship between board audit committee functions and banks financial performance, focusing on commercial banks in Ghana. The dependent variable was financial performance of commercial banks. This variable was made up of two components: ROA and ROE. The independent variables were four board audit committee characteristics: independence, meetings, finance expertise and size. This study attempts to bridge the gap by providing a basis for a thorough and insightful discernment of the influence of board audit committee characteristics on banks' financial performance. Although the causal relationships among the constructs, as shown in Figure 1 seem to be straightforward, in order to make practical statements about board audit committee characteristics and its relation with banks performance, the conceptual framework considers control variables such as bank size and age for further analysis.

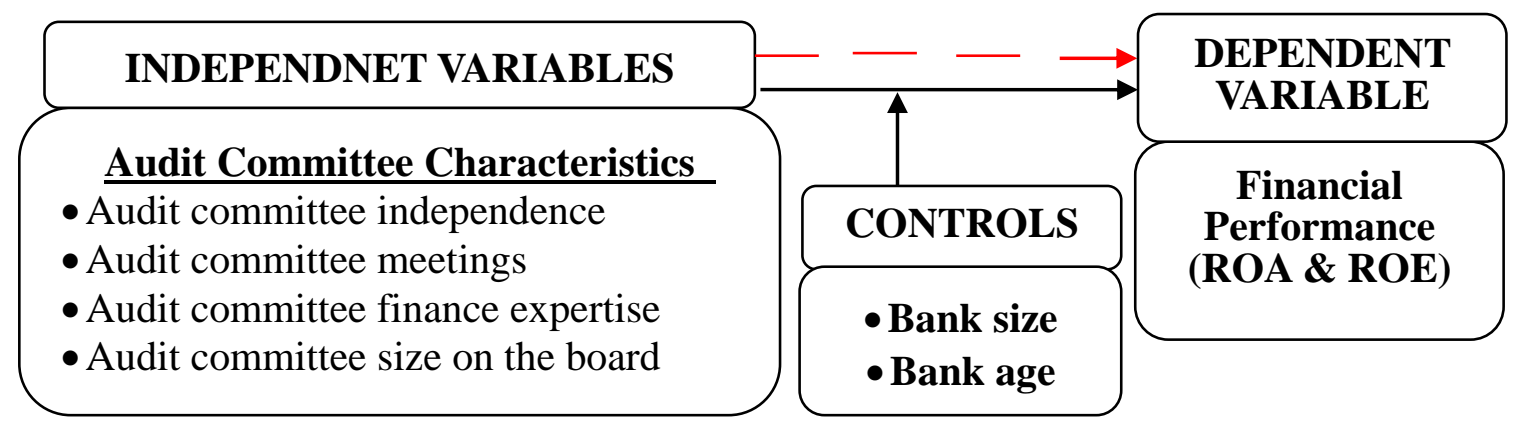

Figure 1. Audit committee characteristics and commercial banks financial performance in

Ghana

Source: Author's construct, 2019

The argument of the study is that, if audit committee characteristics such as their independence, frequency of meetings, members' expertise in finance, and members' size on the board of the institution are in positive terms, it will help boost the financial performance 
of the banks. This is so because they will ensure that the internal control systems of the institutions are adhere to as expected. The study further posits that the influences audit committee characteristics have on banks' financial performance can be boosted or thwarted by the bank size and age. As indicated in Figure 1, the controlling variables for the study are bank size and age.

\section{Research Methods}

The quantitative approach and correlational research design were used for this study. The population of the study was all commercial banks licensed under the Bank and Special Deposit Taking Institution Act with audit committee on their board and offices in Ghana as at December 2018. According to BoG (2019b), there were 23 commercial banks licensed and registered under the Act. However, those commercial banks which were liquidated were not part of the 23 commercial banks.

\subsection{Sample and Sampling Procedure}

The sample size for the study was 13 commercial banks in Ghana. The researcher employed the lottery method of simple random sampling technique to select the 13 commercial banks. Based on the sample frame designed, 46 pieces of paper (23 yes and 23 no) were cut and put in an opaque polythene bag. The papers were labelled as 'YES' and 'NO'. That is, the word 'YES' was written on half of the papers while 'NO' was written on the other half. The researcher assigned numbers to each of the papers in that opaque polythene bag based on the frame such that each bank was represented by a number. The slips of papers were mixed well and one slip picked at a time without looking into it. Each assigned number picked with regard to 'YES' papers were recorded by ticking the corresponding name on the sample frame based on the assigned unique number. In the selection process, the selected and recorded slips were thrown back into the polythene bag before the next one was picked. The process continued until the required number of banks (13) was picked and recorded. This sampling technique was used because the 23 commercial banks were homogeneous and belongs to the same category.

\subsection{Sources of Data}

The study used only secondary data that were measured quantitatively. The data for the audit committees' variables were sourced from the non-financial statements of the annual reports and accounts such as statement on corporate governance, audit committee report and other relevant statements and reports. The market value of equity was obtained from the GSE daily listings. Some of the data were also sourced from the website of Bank of Ghana (BoG), the website of various banks as well as the annual report of banks in Ghana and that of BoG. Fortunately for this study, indicators of audit committee characteristics were already compiled by the BoG, and the study made use of them as expected (BoG, 2019a). That is, the information used to compute and examine the variables were extracted from the reports of BoG, including the financial statements, statement on corporate governance, audit committee report and other relevant statements and reports. 


\section{Ml Macrothink}

International Journal of Accounting and Financial Reporting

ISSN 2162-3082

2020, Vol. 10, No. 1

\subsection{Data Processing and Analysis}

The data were sorted, coded and analysed based on the procedures with the statistical analysis software tool known as the Predictive Analytic Software (PASW) Version 18.0. Statistical tools such as means, standard deviations, Pearson product moment correlation, and linear multiple regression analysis were used to analyse the data. The panel data were generated by pooling time-series observations (2008-2017) across a variety of cross-sectional units (banks). The rational for using this statistical tool is that the variables are all measured numerically. The study used both ROA and ROE to generate the dependent variable (financial performance). These facets of commercial banks' financial performance are the most used dimensions. The predictor variables were the four facets of audit committee characteristics. Also two controlling variables were introduced, which are bank size and age.

\section{Results and Discussion}

The study first examined the relationships between the four characteristics of board audit committee and financial performance of the banks. Also, the relationships between the controls and financial performance of the banks were considered. The results are presented in Table 1. As indicated in the table, audit committee independence $(r=0.564, \mathrm{p}<0.01)$ and finance expertise of the members of the audit committee $(r=0.700, p<0.01)$ have strong, positive and statistically significant relationships with financial performance of the banks. The results further show that there were significant positive relationships between the frequency of meetings of the audit committee members $(r=0.425, p<0.01)$, the size of the audit committee of the governing board $(r=0.328, p<0.01)$, and financial performance.

The results from Table 1 further show that bank size has a positive and significant relationship with the financial performance of the banks $(r=0.176, p<0.05)$. However, in relation to bank age, it has no significant relationship with financial performance of the bank $(r=-0.020, p>0.05)$. This implies that the larger the total assets of a bank, all things being equal, the higher the financial performance of the bank. However, the age of a bank has no meaningful relation with the bank's financial performance.

Table 1. Descriptive and correlation statistics on audit committee characteristics, bank size, bank age, and financial performance of the banks

$\begin{array}{ll}\text { Variables } & \text { FP }\end{array}$

Mean Std. Dev. r $\quad$ Sig.

Audit committee independence (ACIND) $\quad \begin{array}{llll}0.80 & 1.56 & 0.564^{* *} & 0.000\end{array}$

$\begin{array}{lllll}\text { Audit committee meeting (ACMEET) } & -1.39 & 0.89 & 0.425^{* *} & 0.000\end{array}$

Audit committee finance expertise (ACFINEXP) $0.31 \quad 0.63 \quad 0.700^{* *} \quad 0.000$ 
$\begin{array}{lllll}\text { Audit committee size on the board (ACSIZE) } & 30.90 & 15.78 & 0.328^{* *} & 0.000\end{array}$

\begin{tabular}{lllll}
\hline Bank size (BNKSIZE) & 25232.00 & 1.76 & $0.176^{*}$ & 0.032
\end{tabular}

\begin{tabular}{lllll} 
Bank age (BNKAGE) & 29.27 & 30.37 & -0.020 & 0.091 \\
\hline Financial performance (FP) & 4.17 & 0.19 & 1.000 &
\end{tabular}

Source: BoG (2019a); **p<0.01, *<p0.05 (N = 130)

Where $r=$ Correlation coefficient, Std. Dev. $=$ standard deviation

The results from Table 1 show that the four characteristics of board audit committee have positive and significant relationship with the financial performance of the bank. The findings are consistent with that of Ahlulbaitulaah (2018) who found evidence that the independence of an audit committee was negatively related to the occurrence of financial statement fraud. He added that the existence of an independent audit committee was vital to the maintenance of the objectivity, integrity, and quality of a firm's financial performance. However, Aguilera et al. (2018) posit that corporate governance culture such as size of audit committee members on boards of a firm is negatively related to financial performance of the firm. They stated that, the large audit committee size loses concentration and becomes less participative than the smaller one.

Ali (2017) also found out that audit committee meetings have a positive relationship with financial information quality of Sudanese banks. In looking at the relationship between frequency of audit committee meetings and the likelihood of financial statement fraud, Ali (2017) found that the relationship between these two variables is positive. Ali added that the nature of fraud differs by category of bank. However, Ali did not find convincing evidence that banks involved in fraud have fewer audit committee meetings. Furthermore, the findings corroborate with that of Saah (2015) whose findings showed a positive significant relationship between independence and financial expertise of the audit committee and financial performance of medium-scale firms. Saah added that lack of independence of audit committees has rendered regulations and corporate governance reforms dormant in performing their oversight functions.

The study further examined the influence of board audit committee characteristics on the financial performance of selected commercial banks in Ghana during the period of 2008 to 2017. The controlling roles of bank's size and age were considered in the analysis. The results of the analysis are presented in Table 2. Using the multiple regression analysis to analyse the panel data involved testing of two models. In the first model, the four characteristics of board audit committee were entered as independent variables. Statistically, as depicted in Table 2, the characteristics that influenced the financial performance of the commercial banks significantly, in order of importance, were audit committee finance expertise $(\beta=.809, \mathrm{p}<0.01)$ and audit committee size on the board $(\beta=-.203, \mathrm{p}<0.05)$. 
This shows that audit committee size on the board contributes negatively to the banks' financial performance. However, audit committee number of meetings and audit committee independence were non-significance.

Table 2. First and second models on the influence of board audit committee characteristics on financial performance of the banks

\begin{tabular}{|c|c|c|c|c|c|c|c|}
\hline \multirow[b]{2}{*}{ Variables (MODULE ONE) } & \multicolumn{2}{|c|}{ Unstandardized Coefficients } & \multirow{2}{*}{$\begin{array}{c}\begin{array}{c}\text { Standardized } \\
\text { Coefficients }\end{array} \\
\text { Beta }(\beta)\end{array}$} & \multirow[b]{2}{*}{$\mathrm{T}$} & \multirow[b]{2}{*}{ Sig. } & \multicolumn{2}{|c|}{ Collinearity Statistics } \\
\hline & B & Std. Error & & & & Tolerance & VIF \\
\hline Audit committee independence (ACIND) & .000 & .015 & .004 & .031 & .975 & .262 & 3.824 \\
\hline Audit committee meeting (ACMEET) & .007 & .020 & .031 & .329 & .742 & .441 & 2.269 \\
\hline Audit committee finance expertise (ACFINEXP) & .247 & .036 & $.809^{* *}$ & 6.951 & .000 & .286 & 3.494 \\
\hline Audit committee size on the board (ACSIZE) & -.002 & .001 & $-.203^{*}$ & -2.473 & .015 & .575 & 1.740 \\
\hline $\begin{array}{l}\text { Constant } \\
\text { R } \\
\text { R Square } \\
\text { Adjusted R Square } \\
\end{array}$ & & & $\begin{array}{l}4.363 \\
.718 \\
.515 \\
.500 \\
\end{array}$ & & & & \\
\hline Variables (MODULE ONE) & $\mathrm{B}$ & Std. Error & Beta & $\mathrm{t}$ & Sig. & Tolerance & VIF \\
\hline Audit committee independence (ACIND) & .382 & .022 & $.677^{* *}$ & 17.366 & .000 & .627 & 1.596 \\
\hline Audit committee meeting (ACMEET) & .010 & .020 & .047 & .496 & .621 & .436 & 2.295 \\
\hline Audit committee finance expertise (ACFINEXP) & .250 & .036 & $.818^{* *}$ & 6.978 & .000 & .280 & 3.565 \\
\hline Audit committee size on the board (ACSIZE) & -.002 & .001 & $-.188^{*}$ & -2.280 & .024 & .567 & 1.763 \\
\hline Bank size (BNKSIZE) & .037 & .011 & $.067^{* *}$ & 3.436 & .000 & .957 & 1.045 \\
\hline Bank age (BNKAGE) & -.021 & .042 & -.086 & -.526 & .681 & .953 & 1.049 \\
\hline $\begin{array}{l}\text { Constant } \\
\mathrm{R} \\
\mathrm{R} \text { Square } \\
\text { Adjusted R Square }\end{array}$ & & & $\begin{array}{l}4.373 \\
.725 \\
.529 \\
.503\end{array}$ & & & & \\
\hline
\end{tabular}

Source: BoG (2019a); **p<0.01, *<p0.05; $(\mathrm{N}=130)$; Dependent Variable: Financial Performance of Commercial Banks

It is however significant to observe that the total contribution of board audit committee characteristics to the variance in the financial performance of commercial banks is 0.515 with an adjusted $\mathrm{R}^{2}$ of 0.500 . This means that audit committee characteristics are able to explain 51.5 percent of the variance in the financial performance of commercial banks in Ghana. The study therefore, introduced bank size and age as controls to examine their effects.

The findings meanth that as commercial banks develops and improves the accounting/finance expertise of their internal auditors, the higher the banks are able to prevent possible corrupt practices and manipulation of financial statement, and depositors will have much confidence in their banks leading to increase in deposits which the banks invested in a highly yield self-liquidated investments, leading to an increase in profit in the long run (Aguilera et al., 2018). However, increase in audit committee size on the board reduces the financial performance of the banks. This means, banks should not create room for large number of audit committee members to be on the board of the banks.

Thus, all things being equal, a one percent increase on finance/accounting expertise of audit committee members of the bank will lead to 80.9 percent increase in financial performance. This finding supports the assertions of Aguilera et al. (2018) who posit that increase in the number of audit committee members who have the expertise in accounting/ finance affects ROE significantly at all levels of measurement. 


\section{Mll Macrothink}

International Journal of Accounting and Financial Reporting

ISSN 2162-3082

2020, Vol. 10, No. 1

The finding that audit committee independence has no statistically significant influence on financial performance of commercial banks is inconsistent with the submission of Ahlulbaitulaah (2018) who avers that the independence of audit committee is a crucial quality of the audit committee in order to accomplish its oversight role. According to Ahlulbaitulaah (2018), the independent of audit committee from the management is expected to be able to prevent the management from manipulating the earnings of its firm.

In the second model, as presented in Table 2, size and age of the commercial banks in Ghana were entered into the first model to examine its role. The argument here is that the potency of the independent variables can be enhanced by the control variables. That is, bank's size and age can help enhance the contribution of the independent variables on the dependent variable. The results show that audit committee finance expertise $(\beta=.818, p<0.01)$ still contributed significantly to the financial performance of the banks. Also, audit committee independence $(\beta=.677, \mathrm{p}<0.01)$ which was non-significance in the first module became significance when the control variables were considered. Audit committee size on the board $(\beta=-.188, p$ $<0.05)$ was still statistically significant, and contributed negatively to the financial performance of the banks. However, audit committee meeting was still non-significant ( $\beta$ $=.047, \mathrm{p}>0.05)$.

When the two control variables were entered into the first model to generate the second model, the size $(\beta=0.067, \mathrm{p}<0.01)$ was statistically significant while bank age $(\beta=-0.086$, $\mathrm{p}>0.05$ ) has no statistically significant influence on the financial performance of the banks. This shows that the explanatory powers of the independent variables are shared to some extent with the size and age of the banks, especially that of the size of the banks. The total contribution $\left(\mathrm{R}^{2}\right)$ of the variables when the size and age of the banks were introduced to the first model increased from 0.515 to 0.529 , while the adjusted $\mathrm{R}^{2}$ increased to 0.503 . The rate of increase of the $\mathrm{R}^{2}$ was 2.14 percent. Generally, the results show that audit committee independence, finance expertise, audit committee size on the board, and size of banks contributed significantly to the financial performance of the banks.

Specifically, the finding that audit committee finance expertise has a significant influence on financial performance of the banks means that a unit increase in audit committee finance expertise will reflect to an increase in financial performance at 81.8 percent. Thus, when the audit committee is increased by a member with accounting, financial and auditing knowledge, financial performance of the banks increase significantly, suggesting that the higher the percentage of financial experts in the audit committees, the higher the financial performance of the banks. Prior research suggests that financial skill and knowledge is one of the most significant assets that an audit committee should possess because all of the key responsibilities of audit committee members are concerned with accounting, finances and auditing issues (Ahlulbaitulaah, 2018; Ali, 2017; Kuta, 2018).

The functions of audit committee demand the inclusion of a people with finance knowledge as a member of the audit committee as advised by Ahlulbaitulaah (2018). This shows that an audit committee member must have knowledge, understanding or experience in accounting, auditing and finance and be consistently updating his or her knowledgeable of events 
affecting the changes in financial reporting process in order to increase the performance and independency of the audit committee's performance. This is so because the main duty of the audit committee is to review the financial reporting process to ensure the best quality.

\section{Conclusions and Recommendations}

Generally, with the exceptions of audit committee meeting, the findings are in line with the agency theory that audit committee might mitigate agency problems leading to reduced agency cost by aligning the interests of controlling shareholders with those of the bank. When commercial banks create room for meaningful number of audit committee members to be on the board of the banks, particularly those with finance expertise and are independent, it can lead to improvement in the financial performance of the banks. However, the size and age of the bank has a weak influence in the improvement of the finances of the bank. That is, when commercial banks audit committee members are independent, increase the frequency of their meetings, increase the number and quality of financial qualifications of member on board, and also increase the size of the audit committee members on total board membership, it will have a significant influence on their financial performance.

Based on the conclusions of the study, it is recommended to BoG and managers of the various banks to ensure that audit committee members are independent and are meaningfully represented at boards of the bank. Also, based on the finding that audit committee members expertise in finance/accounting has significant influence in financial performance of the bank, it is recommended to BoG and management of the various commercial banks to ensure that audit committee members are people with expertise in accounting/finance.

\section{References}

Aguilera, R. V., Judge, W. Q., \& Terjesen, S. A. (2018). Corporate governance deviance. Academy of Management Review, 43(1), 87-109.

Ahlulbaitulaah, M. M. (2018). An examination of public corporations audits' role in improving financial performance: The case of selected commercial banks in Ghana. Unpublished master's thesis, School of Business, University of Professional Studies, Accra.

Ali, S. H. M. (2017). Role of audit committees in the effectiveness of internal controls of Sudanese banks. Journal of Administrative Sciences of Scientific Research, 23(1), 11-29.

Amoateng, A. K., Osei, K. T., Ofori, A., \& Gyabaa, E. N. (2017). Empirical study on the impact of corporate governance practices on performance: Evidence from SMEs in an emerging economy. European Journal of Accounting Auditing and Finance Research, 5(8), $50-61$.

Anthony, M. C. (2017). Commercial bank risk management: An analysis of the process in Ghana. Unpublished master's thesis, The Wharton School, University of Pennsylvania, Pennsylvania.

Bank of Ghana (BoG). (2019a). Report on the collapse of local banks: Causes and the way forward. Unpublished report, BoG, Accra-Ghana. 


\section{Macrothink}

International Journal of Accounting and Financial Reporting ISSN 2162-3082 2020, Vol. 10, No. 1

Bank of Ghana (BoG). (2019b). Strengthening the financial sector of Ghana: The case of Universal banks, savings and loans, and microfinance institutions. Accra, Ghana: BoG

Kuta, H. I. (2018). Effectiveness of auditing for proper accountability in Nigerian local governments. $\quad$ Retrieved February 17, 2019, from http://papers.ssrn.com/sol3/cfdev/AbsByAuth.cfm?per_id=1594999\#show1955528

National Development Planning Commission (NDPC). (2018). Annual progress report: Mid-term development plan. Accra: NDPC.

Nkegbe, P. K., \& Ustarz, Y. (2015). Banks performance in Ghana: Trends and determinants. Ghana Journal of Development Studies, 12(1/2), 33-52.

Saah, P. E. (2015). Financial management practices and profitability of small and medium-scale entities in the Tamale metropolitan area. Unpublished master's thesis, department of Accounting and Finance, School of Business, College of Art and Social Sciences, Kwame Nkrumah University of Science and Technology, Kumasi.

Saani, A.-J. (2017). Influence of internal control systems on the general performance of microfinance institutions in Ashaiman Municipality. IUG Journal of Humanities and Social Sciences, 2(1), 114-131.

\section{Copyright Disclaimer}

Copyright for this article is retained by the author(s), with first publication rights granted to the journal.

This is an open-access article distributed under the terms and conditions of the Creative Commons Attribution license (http://creativecommons.org/licenses/by/4.0/) 